\title{
PENENTUAN PREMI ASURANSI JIWA BERJANGKA MENGGUNAKAN METODE LAST SURVIVOR
}

\author{
Aulia Puteri Amari, Neva Satyahadewi, Hendra Perdana
}

\section{INTISARI}

\begin{abstract}
Asuransi jiwa yang berkembang di Indonesia ada dua macam, yaitu asuransi jiwa perorangan (single life) dan asuransi jiwa bersama (multi life). Asuransi multi life memiliki dua istilah berdasarkan status kematian dari kumpulan tertanggung yaitu joint life dan last survivor. Asuransi joint life memberikan status kematian jika salah satu dari anggota kelompok mengalami kematian selama masa pertanggungan asuransi. Asuransi last survivor memberikan status kematian jika tersisa hanya satu anggota yang bertahan hidup hingga akhir masa pertanggungan asuransi berakhir. Penelitian ini bertujuan untuk mengetahui besarnya premi tahunan asuransi jiwa berjangka last survivor tiga orang tertanggung dengan usia suami 30 tahun, usia istri 25 tahun dan usia anak 5 tahun. Perhitungan premi tahunan yang dibayarkan tertanggung dibagi menjadi dua yaitu pada anak laki-laki dan anak perempuan dengan tingkat suku bunga 6\% dan benefit yang didapatkan sebesar Rp300.000.000 adalah Rp4.627.901 untuk anak perempuan dan Rp4.660.859 untuk anak laki-laki. Berdasarkan penelitian ini juga diperoleh besar premi tahunan asuransi jiwa berjangka last surivor bergantung pada tingkat suku bunga, jenis kelamin dan usia tertanggung. Laki-laki membayar premi lebih mahal dari perempuan. Semakin tinggi tingkat suku bunga maka semakin kecil premi yang dibayarkan sedangkan premi semakin mahal jika usia nasabah semakin tinggi.
\end{abstract}

Kata kunci: Asuransi Jiwa Joint Life, Last Survivor, Premi, Santunan.

\section{PENDAHULUAN}

Asuransi jiwa merupakan salah satu upaya perlindungan yang diberikan oleh pihak penanggung (perusahaan asuransi jiwa) terhadap risiko jiwa yang akan dialami pihak tertanggung. Asuransi jiwa yang berkembang di Indonesia ada dua macam, yaitu asuransi jiwa perorangan (single life) dan asuransi jiwa bersama (multi life). Perbedaan antara asuransi jiwa perorangan dengan asuransi jiwa bersama terletak pada peserta yang mengikuti asuransi tersebut. Pada asuransi jiwa perorangan, perusahaan asuransi memberikan perlindungan untuk satu orang (tunggal) tertanggung, sedangkan jumlah tertanggung pada pada asuransi jiwa bersama lebih dari satu orang. Salah satu produk asuransi jiwa bersama adalah asuransi status hidup gabungan untuk asuransi bersama (joint life insurance) [1].

Asuransi multi life memiliki dua istilah berdasarkan status kematian dari kumpulan tertanggung yaitu joint life dan last survivor [2]. Perbedaan asuransi multi life ini adalah pada waktu pemberian uang pertanggungannya. Asuransi joint life yaitu asuransi jiwa dimana uang pertanggungan dibayarkan pada pasangan yang ditinggalkan apabila terjadi kematian pada pasangan tersebut. Asuransi last survivor yaitu asuransi jiwa yang uang pertanggungan dibayarkan apabila salah satu tertanggung masih tetap hidup hingga akhir masa waktu pertanggungan. Kasus asuransi last survivor menggunakan anuitas last survivor. Anuitas last survivor adalah suatu rangkaian pembayaran oleh dua orang tertanggung atau lebih dimana pembayaran premi terjadi apabila salah satu tertanggung masih tetap hidup hingga akhir masa waktu pertanggungan.

Penelitian ini bertujuan menganalisis perhitungan premi tahunan untuk pemegang asuransi jiwa berjangka last survivor dalam kasus tiga orang tertanggung, yaitu kedua orang tua dan anaknya. 
Perhitungan dibagi menjadi dua, yaitu pada saat pasangan suami istri memiliki anak laki-laki dan saat pasangan suami istri memiliki anak perempuan. Premi tahunan didapatkan dari mengumpulkan informasi mengenai jangka waktu asuransi, santunan, tingkat suku bunga, serta usia kedua orang tua dan anaknya. Langkah selanjutnya menghitung anuitas awal last survivor dari ketiga orang tertanggung. Langkah terakhir menghitung nilai premi tunggal asuransi jiwa berjangka last survivor dan selanjutnya menghitung nilai premi tahunan asuransi jiwa berjangka last survivor untuk ketiga orang tertanggung.

\section{PELUANG HIDUP GABUNGAN}

Terdapat dua orang peserta asuransi berusia $x$ dan $y$ tahun dengan asumsi $(x)$ dan $(y)$ akan tetap hidup selama $n$ tahun adalah saling bebas, maka peluang hidup gabungannya, yaitu [2]:

$$
{ }_{n} p_{x y}=\left({ }_{n} p_{x}\right)\left({ }_{n} p_{y}\right)
$$

Peluang salah satu $(x)$ dan $(y)$ meninggal dunia dalam jangka waktu $n$ tahun adalah:

$$
\begin{aligned}
{ }_{n} q_{x y} & =1-{ }_{n} p_{x y} \\
& =1-\left({ }_{n} p_{x}\right)\left({ }_{n} p_{y}\right)
\end{aligned}
$$

Peluang bersama $(x)$ dan $(y)$ meninggal dunia dalam jangka waktu $n$ tahun adalah:

$$
{ }_{n} q_{x y}=\left({ }_{n} q_{x}\right)\left({ }_{n} q_{y}\right)
$$

Peluang $(x)$ dan $(y)$ sedikitnya satu yang bertahan hidup dalam jangka waktu $n$ tahun, yaitu:

$$
{ }_{n} p_{\overline{x y}}=1-{ }_{n} q_{x y}
$$

Terdapat tiga orang peserta asuransi berusia $x, y$ dan $z$ tahun dengan asumsi $(x),(y)$ dan $(z)$ akan tetap hidup selama $n$ tahun adalah saling bebas, maka peluang hidup gabungannya, yaitu:

$$
{ }_{n} p_{x y z}=\left({ }_{n} p_{x}\right)\left({ }_{n} p_{y}\right)\left({ }_{n} p_{z}\right)
$$

Peluang salah satu $(x),(y)$ dan $(z)$ meninggal dalam jangka waktu $n$ tahun adalah:

$$
\begin{aligned}
{ }_{n} q_{x y z} & =1-{ }_{n} p_{x y z} \\
& =1-\left({ }_{n} p_{x}\right)\left({ }_{n} p_{y}\right)\left({ }_{n} p_{z}\right)
\end{aligned}
$$

Peluang bersama $(x),(y)$ dan $(z)$ meninggal dunia dalam jangka waktu $n$ tahun adalah:

$$
{ }_{n} q_{\overline{x y z}}=\left({ }_{n} q_{x}\right)\left({ }_{n} q_{y}\right)\left({ }_{n} q_{z}\right)
$$

Peluang $(x),(y)$ dan $(z)$ sedikitnya satu yang bertahan hidup dalam jangka waktu $n$ tahun, yaitu:

$$
\begin{aligned}
{ }_{n} p_{\overline{x y z}} & =1-{ }_{n} q_{\overline{x y z}} \\
& ={ }_{n} p_{x}+{ }_{n} p_{y}+{ }_{n} p_{z}-\left({ }_{n} p_{x}\right)\left({ }_{n} p_{y}\right)-\left({ }_{n} p_{x}\right)\left({ }_{n} p_{z}\right)-\left({ }_{n} p_{y}\right)\left({ }_{n} p_{z}\right)+\left({ }_{n} p_{x}\right)\left({ }_{n} p_{y}\right)\left({ }_{n} p_{z}\right)
\end{aligned}
$$

keterangan:

$$
{ }_{n} p_{x} \quad=\text { peluang seseorang berusia } x \text { tahun akan bertahan hidup hingga jangka waktu } n \text { tahun }
$$

${ }_{n} p_{y} \quad=$ peluang seseorang berusia $y$ tahun akan bertahan hidup hingga jangka waktu $n$ tahun

${ }_{n} p_{z} \quad=$ peluang seseorang berusia $z$ tahun akan bertahan hidup hingga jangka waktu $n$ tahun

\section{TINGKAT SUKU BUNGA}

Tingkat suku bunga terdiri atas dua jenis, yaitu bunga tunggal dan bunga majemuk. Bunga tunggal atau yang sering disebut dengan bunga sederhana, dihitung berdasarkan pada perbandingan pokok dengan jangka waktu investasinya. Sedangkan bunga majemuk merupakan perhitungan bunga yang besar pokok dan jangka investasinya ialah jumlahan antara besar pokok sebelumnya dengan besar bunga yang diperoleh [3]. 
Nilai sekarang adalah investasi sebesar 1 yang akan terakumulasi menjadi $(i+1)$ pada akhir periode ke 1 [4]. Nilai sekarang juga bisa disebut dengan faktor diskonto yang dinotasikan dengan $v$, yaitu:

$$
v^{t}=\frac{1}{(i+1)^{t}}
$$

keterangan:

$i \quad$ = tingkat suku bunga

$t=$ periode

$v^{t}=$ fungsi diskonto untuk periode ke- $t$

\section{ASURANSI JIWA BERJANGKA}

Asuransi jiwa berjangka adalah asuransi yang mempunyai jangka waktu tertentu. Manfaat hanya dapat diperoleh jika tertanggung meninggal sepanjang waktu perjanjian dan sampai waktu jatuh tempo, sedangkan jika tertanggung masih hidup setelah waktu jatuh tempo maka ahli waris tidak akan mendapatkan manfaat [2]. Asuransi jiwa berjangka $n$-tahun dengan memberikan satu unit manfaat pada akhir tahun kematian, diperoleh:

$$
\begin{aligned}
b_{k+1} & = \begin{cases}1 & , k=0,1,2, \ldots, n-1 \\
0 & , k=n, n+1, \ldots\end{cases} \\
v_{k+1} & = \begin{cases}v^{k+1} & , k=0,1,2, \ldots, n-1 \\
0 & , k=n, n+1, \ldots\end{cases} \\
Z & = \begin{cases}v^{k+1} & , k=0,1,2, \ldots, n-1 \\
0 & , k=n, n+1, \ldots\end{cases}
\end{aligned}
$$

Nilai sekarang aktuaria untuk asuransi jiwa berjangka $n$-tahun adalah:

$$
E(Z)=A_{x y: n}^{1}=\sum_{k=0}^{n-1}\left(b_{k+1}\right)\left(v_{k+1}\right)\left({ }_{k} p_{x}\right)\left(q_{x+k}\right)
$$

\section{ANUITAS HIDUP AWAL LAST SURVIVOR BERJANGKA}

Anuitas adalah suatu pembayaran dalam jumlah tertentu, yang dilakukan setiap selang waktu tertentu secara berkelanjutan. Suatu anuitas yang pasti dilakukan selama dalam jangka pembayaran disebut anuitas pasti, jika pembayaran yang dilakukan tergantung hidup matinya seseorang disebut anuitas hidup. Nilai tunai anuitas hidup awal diperhitungkan pada awal setiap jangka waktu penerimaan anuitas.

Besar penerimaan anuitas last survivor setiap awal periode selama $n$ periode dengan tingkat suku bunga $i$ per periode adalah 1 rupiah untuk tiga orang berusia $x, y$ dan $z$ adalah [2]:

$$
\begin{aligned}
\ddot{a}_{\overline{x y z: n}} & =1+v^{1}{ }_{1} p_{\overline{x y z}}+v^{2}{ }_{2} p_{\overline{x y z}}+\ldots+v^{n-1}{ }_{n-1} p_{\overline{x y z}} \\
& =\sum_{k=0}^{n-1} v^{k}{ }_{n} p_{\overline{x y z}}
\end{aligned}
$$

\section{PREMI TAHUNAN ASURANSI JIWA BERJANGKA LAST SURVIVOR}

Premi adalah sejumlah uang yang wajib dibayarkan oleh pemegang polis kepada perusahaan asuransi dengan cara yang telah ditentukan dan sekaligus menjadi syarat diperolehnya perlindungan asuransi Premi tahunan pada asuransi last survivor berjangka merupakan besarnya biaya yang ditanggung oleh peserta asuransi (dalam hal ini tiga orang) yang dibayarkan setiap tahun agar 
memperoleh santunan ketika kedua orang lainnya meninggal. Perhitungan premi tahunan pada asuransi last survivor diturunkan dari persamaan dasar perhitungan premi tunggal, yaitu nilai tunai premi sama dengan nilai

tunai santunan [2]. Premi tahunan menggunakan anuitas awal untuk asuransi jiwa berjangka last survivor dengan 3 orang tertanggung $x, y$ dan $z$ yaitu:

$$
P\left(A_{x y z: n}^{1}\right)=R \times \frac{A_{x y z: n}^{1}}{\ddot{a}_{\overline{x y z}: n}}
$$

keterangan:

$\mathrm{R}=$ Benefit yang diterima

\section{STUDI KASUS}

Pada penelitian ini akan diberikan studi kasus sebagai simulasi penentuan premi asuransi jiwa berjangka untuk kasus tiga orang tertanggung yaitu kedua orang tua dan anaknya menggunakan asuransi jiwa berjangka dengan metode last survivor. Proses penyelesaian perhitungan premi menggunakan bantuan software Microsoft Excel. Perhitungan premi tahunan asuransi jiwa berjangka dengan metode last survivor akan diterapkan dalam contoh kasus sebagai berikut:

Contoh kasus 1:

Pada kehidupan sehari-hari musibah bisa terjadi kapan saja. Musibah tersebut dapat berupa penyakit atau kecelakaan yang dapat mengakibatkan kecacatan atau bahkan kematian. Menyadari hal tersebut seorang pria yang berusia 30 tahun mengajak istrinya yang berusia 25 tahun dan anak perempuannya yang berusia 5 tahun untuk membeli polis asuransi jiwa berjangka last survivor. Premi akan dibayarkan setahun sekali selama 30 tahun dan dibayarkan pada setiap awal periode. Besar santunan yang akan diterima Rp300.000.000 dengan suku bunga 6\%.

Nilai Anuitas Last Survivor menggunakan Persamaan (12):

$$
\begin{aligned}
\ddot{a}_{\overline{30,25,5: 30}} & =\sum_{k=0}^{30-1}\left(v^{k}\right)\left({ }_{k} p_{\overline{30,25,5}}\right) \\
& =\sum_{k=0}^{30-1}\left(v^{k}\right)\left(1-\left(1-{ }_{k} p_{30}\right)\left(1-{ }_{k} p_{25}\right)\left(1-{ }_{k} p_{5}\right)\right. \\
& =14,7648
\end{aligned}
$$

Nilai sekarang asuransi jiwa berjangka menggunakan Persamaan (11):

$$
\begin{aligned}
A_{\overline{30,25,530 \mid}}^{1} & =\sum_{k=0}^{n-1} 1\left(v^{k+1}\right)\left({ }_{k} p_{\overline{x y z}}\right)\left(q_{\overline{x+k ; y+k ; z+k}}\right) \\
& =\sum_{k=0}^{30-1} 1\left(v^{k+1}\right)\left({ }_{k} p_{\overline{30,25,5}}\right)\left(q_{\overline{30+k ; 25+k ; 5+k}}\right) \\
& =0,2278
\end{aligned}
$$

Premi tahunan Last Survivor menggunakan Persamaan (13):

$$
\begin{aligned}
P\left(A_{x y z: n}^{1}\right) & =R\left(\frac{A_{\overline{30,25,5: 30 \mid}}^{1}}{\ddot{a}_{\overline{30,25,5: 30 \mid}}^{1}}\right) \\
& =300.000 .000\left(\frac{0,2278}{14,7648}\right) \\
& =R p 4.627 .901
\end{aligned}
$$

Berdasarkan contoh kasus tiga orang tertanggung dengan usia suami 30 tahun, usia istri 25 tahun dan usia anak perempuannya 5 tahun dengan jangka waktu 30 tahun dan tingkat suku bunga $6 \%$ serta 
benefit yang didapatkan sebesar Rp300.000.000 maka premi yang harus dibayarkan disetiap awal tahun adalah sebesar Rp4.627.901.

Contoh kasus 2:

Seorang pria yang berusia 30 tahun mengajak istrinya yang berusia 25 tahun dan anak laki-lakinya yang berusia 5 tahun untuk membeli polis asuransi jiwa berjangka last survivor. Premi akan dibayarkan setahun sekali selama 30 tahun dan dibayarkan pada setiap awal periode. Besar santunan yang akan diterima Rp300.000.000 dengan suku bunga 6\%.

Nilai Anuitas Last Survivor menggunakan Persamaan (12):

$$
\begin{aligned}
\ddot{a}_{\overline{30,25,530}} & =\sum_{k=0}^{30-1}\left(v^{k}\right)\left({ }_{k} p_{\overline{30,25,5}}\right) \\
& =\sum_{k=0}^{30-1}\left(v^{k}\right)\left(1-\left(1-{ }_{k} p_{30}\right)\left(1-{ }_{k} p_{25}\right)\left(1-{ }_{k} p_{5}\right)\right. \\
& =14,7648
\end{aligned}
$$

Nilai sekarang asuransi jiwa berjangka menggunakan Persamaan (11):

$$
\begin{aligned}
A_{30,25,5: 30 \mid}^{1} & =\sum_{k=0}^{n-1} 1\left(v^{k+1}\right)\left({ }_{k} p_{\overline{x y z}}\right)\left(q_{\overline{x+k ; y+k ; z+k}}\right) \\
& =\sum_{k=0}^{30-1} 1\left(v^{k+1}\right)\left({ }_{k} p_{\overline{30,25,5}}\right)\left(q_{\overline{30+k ; 25+k ; 5+k}}\right) \\
& =0,2294
\end{aligned}
$$

Premi tahunan Last Survivor menggunakan Persamaan (13):

$$
\begin{aligned}
P\left(A_{x y z: n}^{1}\right) & =R\left(\frac{A_{\overline{30,25,5: 30 \mid}}^{1}}{\ddot{a}_{\overline{30,25,5: 30}}}\right) \\
& =300.000 .000\left(\frac{0,2294}{14,7648}\right) \\
& =R p 4.660 .859
\end{aligned}
$$

Berdasarkan contoh kasus tiga orang tertanggung dengan usia suami 30 tahun, usia istri 25 tahun dan usia anak laki-lakinya 5 tahun dengan jangka waktu 30 tahun dan tingkat suku bunga $6 \%$ serta benefit yang didapatkan sebesar Rp300.000.000 maka premi yang harus dibayarkan disetiap awal tahun adalah sebesar Rp4.660.859.

\begin{tabular}{|c|c|c|c|}
\hline \multirow{2}{*}{$\begin{array}{l}\text { Suku } \\
\text { Bunga }\end{array}$} & \multicolumn{3}{|c|}{ Usia } \\
\hline & $x=25, y=30, z=5$ & $x=30, y=25, z=5$ & $x=30, y=30, z=5$ \\
\hline $1 \%$ & Rp 9.920 .121 & Rp 10.110 .799 & Rp 10.433 .321 \\
\hline $2 \%$ & $\begin{array}{ll}\mathrm{Rp} & 8.519 .448\end{array}$ & $\begin{array}{ll}\operatorname{Rp} & 8.693 .669\end{array}$ & $\begin{array}{ll}\mathrm{Rp} & 8.991 .856\end{array}$ \\
\hline $3 \%$ & Rp 7.291.279 & $\begin{array}{ll}\mathrm{Rp} & 7.449 .698\end{array}$ & $\begin{array}{ll}\mathrm{Rp} & 7.724 .736\end{array}$ \\
\hline $4 \%$ & Rp 6.223 .204 & $\operatorname{Rp} \quad 6.366 .590$ & 6.619 .804 \\
\hline
\end{tabular}

\section{PERBANDINGAN PREMI BERDASARKAN USIA DAN TINGKAT SUKU BUNGA}

Besarnya premi ditentukan oleh suku bunga, usia dan jenis kelamin, sehingga untuk melihat besarnya perbedaan premi dibuatlah 3 perbandingan. Perbandingan pertama yaitu ketika usia suami 25 tahun, usia istri 30 tahun dan usia anak perempuannya 5 tahun. Kedua saat usia suami 30 tahun, usia istri 25 tahun dan usia anak perempuannya 5 tahun. Ketiga pada saat usia suami dan istri sama yaitu 30 tahun dan usia anaknya 5 tahun, dengan tingkat suku bunga $1 \%$ sampai dengan $6 \%$ maka didapat hasil sebagai berikut:

Tabel 1 Perbandingan Premi dan Tingkat Suku Bunga 


\begin{tabular}{|l|ll|l|l|}
$5 \%$ & $\mathrm{Rp} 5.301 .543$ & $\mathrm{Rp} 5.430 .755$ & $\mathrm{Rp} 5.663 .564$ \\
\hline $6 \%$ & $\mathrm{Rp} 4.511 .947$ & $\mathrm{Rp} 4.627 .900$ & $\mathrm{Rp}$ & 4.841 .778 \\
\hline
\end{tabular}

Berdasarkan Tabel 1 diperoleh informasi ketika usia suami lebih tua dari usia istri maka premi yang didapatkan lebih besar daripada saat usia istri lebih tua dari usia suami dan ketika usia suami dan istri sama maka premi yang harus dibayarkan lebih besar daripada ketika suami memiliki usia yang berbeda dengan istri. Semakin tinggi tingkat suku bunga maka semakin kecil premi yang harus dibayarkan oleh tertanggung dan semakin rendah tingkat suku bunga maka semakin besar premi yang harus dibayarkan oleh tertanggung. Sebagai contoh saat usia suami 30 tahun, usia istri 25 tahun dan usia anaknya 5 tahun dengan suku bunga 6\% premi yang didapatkan adalah sebesar Rp4.627.900. Premi yang didapatkan lebih besar dibandingkan saat usia suami 25 tahun, usia istri 30 tahun dan usia anaknya 5 tahun dengan suku bunga 6\% yaitu Rp4.511.947.

\section{PENUTUP}

Asuransi jiwa last survivor adalah asuransi jiwa dimana sekelompok orang tertanggung mendapat santunan jika salah satu anggota bertahan hidup hingga akhir jangka waktu asuransi. Suami, istri dan anak yang masing-masing berusia 30 tahun, 25 tahun dan 5 tahun mengikuti polis asuransi dengan jangka waktu 30 tahun. Besar premi yang didapatkan dengan menggunakan asuransi jiwa berjangka menggunakan metode last survivor menggunakan Tabel Mortalita Indonesia 2011 dengan santunan sebesar Rp300.000.000 dan tingkat suku bunganya 6\% adalah sebesar Rp4.627.901,00.

\section{DAFTAR PUSTAKA}

[1]. Sembiring, R.K. Buku Materi Pokok Asuransi I. Karunika Universitas Terbuka, Jakarta; 1986.

[2]. Bowers N. L., Gerber H. U., Hickman J. C., Jones D. A., Nesbitt C. J. Actuarial Mathematics Second Edition. Illinois: Society Of Actuaries; 1997.

[3]. Futami, T. Matematika Asuransi Jiwa Bagian II. Tokyo: Incorporated Foundation Oriental Life Insurance Cultural Development Center; 1994.

[4]. Futami, T. Matematika Asuransi Jiwa Bagian I. Tokyo: Incorporated Foundation Oriental Life Insurance Cultural Development Center; 1993.

$\begin{array}{lll}\text { AULIA PUTERI AMARI } & : & \begin{array}{l}\text { Jurusan Matematika FMIPA UNTAN, Pontianak } \\ \text { apamari25@ gmail.com }\end{array} \\ \text { NEVA SATYAHADEWI } & : & \begin{array}{l}\text { Jurusan Matematika FMIPA UNTAN, Pontianak } \\ \text { neva.satya @ math.untan.ac.id }\end{array} \\ \text { HENDRA PERDANA } & : & \begin{array}{l}\text { Jurusan Matematika FMIPA UNTAN, Pontianak } \\ \text { hendra.perdana@ math.untan.ac.id }\end{array}\end{array}$

